\title{
Family and Volunteer Partner Opinions on Young Athletes Project
}

\author{
Ahmet Bildiren $^{1}$ \\ ${ }^{1}$ Department of Special Education, Adnan Menderes University, Aydın, Turkey \\ Correspondence: Ahmet Bildiren, Department of Special Education, Adnan Menderes University, 09010 \\ Efeler/Aydın, Turkey. E-mail: abildiren@adu.edu.tr
}

Received: January 22, 2018

Accepted: February 26, 2018

Online Published: April 23, 2018

doi:10.5539/ies.v11n5p46

URL: https://doi.org/10.5539/ies.v11n5p46

\begin{abstract}
The objective of this study was to examine the impacts during the pre-school period of Special Olympics activities on the attitudes of children with special needs as well as the families of normal developing children along with the teacher candidates who are likely to work with disabled children in the future (volunteers). The study group was comprised of the parents of 45 special athletes from 6 different cities who have participated in the Young Athletes Project and whose opinions have been asked during the pre-test along with the parents of 60 partner athletes along with 119 volunteer partners, parents of 46 special athletes and 51 partner athletes as well as 107volunteer partners. Children with special needs and normal developing children were placed in an 8 week sports and game program within the scope of an integrated approach. Qualitative and quantitative data collection techniques were used in the study. The study results set forth that Young Athletes project has a positive impact on the opinions of the families of children with special needs and normal developing children as well as the opinions of volunteer partners.
\end{abstract}

Keywords: special needs children, Special Olympics, parents

\section{Introduction}

It is observed as a result of the worldwide increase in the number of studies on special education that individuals with special needs are able to integrate more with the society in other words that they are able to experience lives similar to those of their normal developing peers (Kargın 2004; Salend, 2001; Sucuoğlu \& Kargın, 2012; Turnbull, Turnbull, Shank, Smith, \& Leal, 2002). When an examination was carried out with regard to studies for enabling individuals with special needs to participate more in social life (Cavkaytar, 2000; Gözün \& Yıkmış, 2004; Smith, Polloway, Patton, \& Dowdy, 2008; Sucuoğlu \& Bakkaloğlu, 2013) it is possible to indicate that they result in positive developments in different aspects of life starting from the early education programs that should be applied on individuals with special needs at an early age to providing an occupation. It can be indicated as a result of the examination of results acquired from different studies on this subject that individuals with special needs should be allowed to integrate more easily with the society instead of excluding them and that there is a consensus on the idea that they should benefit equally from all educational opportunities provided to normal developing children based on their own skills, competencies and requirements (Hallahan \& Kauffman, 2006; Heward, 2013; Odom, Horner, Snell, \& Blacher, 2007; Weber \& Scheuermann, 2008). During this period, it is observed that the importance given to the education of individuals with special needs is gaining importance every day and that equal rights of all individuals for having access to receiving a proper education based on their own requirements has become an important principle of our education system due to the principle of equal opportunity in education regardless of whether the individual has special needs or not (IDEA, 2012; MEB, 2012). The most important aspect of this principle is the necessity for individuals with special needs to receive education based on their individual characteristics together with normal developing individuals by way of integrated education. Indeed, researchers have indicated that individuals with special needs may gain sufficient academic and social behaviors by means of a properly structured integrated education and hence, the quality and quantity of the interaction between disabled individuals and their normal developing peers may be increased in this manner and that there might be positive changes in the attitudes of normal developing individuals towards individuals with special needs (Kaner, 2000; Kırcaali-İftar, 1998; Güzel-Özmen, 2003; Kargın, Acarlar, \& Sucuoğlu, 2003; Öncül \& Batu, 2005).

Parents who have a critical role in the support of the development of children with special needs undergo significant emotional and psychological difficulties. Studies carried out in Turkey on the parents of mentally disabled children proposed that they are more depressed and anxious in comparison with the parents of children without any mental disabilities, that they feel more guilt and shame while also having anxieties with regard to the 
care of their children in the future and that they also have concerns resulting from the limitations imposed on their family life as well as the hardships brought about by the lifelong care of such children (Aysan \& Özben, 2007; Bahar, Savaş, \& Parlak 2004; Çürük, 2008; Dereli \& Okur, 2008; Karaçengel, 2007; Natan, 2007; Uğuz, İnanç, \& Çolakkadıoglu, 2004). Therefore, families approach integrated education with suspicion in the education of children with special needs. Hence, it is thought that activities which bring together children with special needs and normal developing children may have a positive impact on the attitudes of families.

Similar negative attitudes have also been observed in teachers who are among the most important factors of integration (Diken \& Sucuoğlu, 1999; Gözün \& Yıkmış, 2004; Orel, Zerey, \& Töret, 2004; Rakap \& Kaczmarak, 2010; Uysal, 2003). However, it is stated that all educators who take part in the integration education should develop positive attitudes towards individuals with special needs in order to ensure that the education is carried out successfully (Bondurant, 2004; Campbell, Gilmore, \& Cuskelly, 2003; Fakolade, Adenıy1, \& Tella, 2009; Firat, 2014; Mastropieri \& Scruggs, 2001; Olson, 2003; Villa \& Thousand, 2003). In this regard, developing of a positive attitude by the teachers can be pointed as a significant factor for fully benefiting from the integration applications of individuals with special needs.

"Young Athletes Project" has been ongoing in Turkey as a result of the aforementioned concerns for developing positive attitudes in both families and teachers as well as for ensuring that positive attitudes are developed in children starting at an early age. Young Athletes Project is an educative game-based project with an objective of bringing together children with special needs and normal developing children between the ages of 2-7 under the same roof for improving their basic motor skills. The goal of the project is to improve the basic motor skills of children in addition to eliminating prejudices at an early age thereby improving their skills to take part in the society together. The project is currently applied in 34 countries in the world with a wide network that encompasses 74.000 athletes. A pilot application has been carried out in Turkey to be shaped according to its own cultural needs as well as the social needs and the needs of the children. The Turkey application of the project has been designed based on experiences acquired from the pilot application. Kindergartens to which children with special needs attend along with kindergartens with normal developing children as well as universities make up the partners of the project (https://www.soturkiye.org.tr/).

The objective of this study was to examine the impacts of Special Olympics activities on the attitudes of children with special needs as well as the families of normal developing children along with the teacher candidates who are likely to work with disabled children in the future (volunteers).It is thought that the study result will contribute to improving the attitudes towards integration education of both families and teacher candidates, thus supporting the application of integration education. In this regard, answers to the following questions were sought for:

1) Do the opinions of the families of children with special needs (special athlete parents) change after the Young Athletes Project?

2) Do the opinions of the families of normal developing children (partner athlete parents) change after the Young Athletes Project?

3) Do the opinions of teacher candidates (volunteer partners) change after the Young Athletes Project?

\section{Method}

This was a descriptive study which was carried out using the case study method. This method enables the carrying out of in-depth examinations on a certain topic or situation. Indeed, qualitative and quantitative data acquisition methods can be used in this method (Yıldırım \& Şimşek, 2013; Patton, 1990; Cohen \& Manion, 1997).

The interview form used in this study was developed based on literature (Yıldırım \& Şimşek, 2013; Miles \& Huberman, 1994) which was then presented for expert opinion. The interview form was finalized in accordance with the criticisms acquired. "Interview" method was used in the study as a data acquisition tool. Data obtained by way of the interview method were digitizes thus enabling the calculation of frequency and percentages. Following the completion of the Young Athletes Project, interviews were repeated with the special athlete parents, partner athlete parents and volunteer teacher candidates who were then recorded. The interview forms were read separately by the researcher and were then classified in accordance with the similarities of the statements. The classified statements were compared and finalized by the researcher. The interview forms prior to and after the Young Athletes Project along with the classified statements were tabulated after which the frequency and the percentages were calculated.

In depth interviews as part of the study were carried out with some of the parents of disabled children and normal developing children as well as volunteer teachers $(n=20)$ for ensuring that the Young Athletes Project is evaluated by all segments included in the organization. In-depth interviews were carried out with parents of special athlete 
and partner athletes, project officers, teachers and project volunteers in the cities of Ankara, Burdur, İzmir and Sakarya.

\subsection{Young Athletes Activity Program and Its Application}

Young Athletes Special Olympics is a sports and game program for children with and without special needs for children whose ages vary between 2 and 7.Young Athletes display fundamental sports skills such as running, kicking and throwing. Young Athletes enable the families, teachers and all members of the society to share the fun of sports together with children. The activity program has been prepared by special Olympics and an activity guide has been prepared. According to the activity guide, the provincial coordinators received training from project general coordinatorship. The provincial coordinators announced the project in their own cities thus determining the special athletes and partner athlete parents along with volunteer partners who wish to take part. Children aged between 2-7 with and without special needs along with volunteer partners participated in activities for 2 hours per week in the accompaniment of the project coordinators for a period of 8 weeks in accordance with the activity guide.

Children with and without special needs were matched during the activities following the warm-up so that they could carry out activities together. In the meantime, volunteer partners helped the children. Volunteer partners supported the children with and without special needs for increasing their communication.

\subsection{Participant (Subject) Characteristics}

The project brought together children between the ages of 2-7 with and without special needs at the cities of Ankara, Burdur, İzmir, Sakarya, Aydın and Istanbul and game-focused activities were carried out. In this study, there are 45 special athletes along with 60 partner athlete parents and 119 volunteer partners whose opinions have been taken in the pre-test; 46 special athletes along with 51 partner athlete parents and 107 volunteer partners whose opinions have been taken in the final test. Special athletes who participated in the study were children with mental disabilities, autism spectrum disorder and down syndrome. The age average of the special children was 5.6. The partners of these special children were normal developing children. Their age average was 5.3.

\subsection{Sampling Procedures}

A pre-interview was made with special athlete parents and partner athlete parents along with the volunteer teacher candidates to be included in the project by the project coordinator at the city where the project is continued during which the objective of the study was told and the interview form was shown in addition to providing a guarantee for the confidentiality of identity information. It was stated that the principle of voluntariness is sought for and appointments were made with the volunteer family and teacher candidates. Interviews with volunteer subjects were carried out by the project coordinators. The interviews were recorded in notes after which these notes were shown to the subject to take their final approvals.

\subsubsection{Measures}

Parent and volunteer opinions on the Young Athletes Project were acquired by way of "Young Athletes Opinion Survey" and "Semi-Structured Interview Form". The survey form developed by the researcher for determining the opinions on special Olympics of special athlete and partner parents along with the partner volunteer. Survey method is used in studies since it was not possible to directly observe certain behaviors along with various intellectual, emotional, motivational, perceptive characteristics of the individuals (Borg, J. Gall, \& P. Gall, 1993; Ekiz, 2003; Fraenkel \& Wallen, 1996; Karasar, 2003). The draft survey form was presented for analysis to related experts in the field and the required revisions were made. The reliability coefficient of the survey (Cronbach Alpha) was determined as 0.70 . The prepared survey form was then applied to 10 special athlete and partner parents and 10 partner volunteers as pilot application. A survey comprised of 15 items for special athlete parents and 13 items for partner parents and partner volunteers were prepared following the analysis of the acquired data.

On the other hand, interviews were carried out based on the principle of voluntariness with 20 participants using the semi-structured interview form in order to make an in-depth examination of the opinions of special athlete and partner parents and partner volunteers on the Young Athletes Project. The questions included in the interview were questioned in-depth throughout the interview. The interview data were recorded on tape.

Frequency and percentage calculations were completed for the quantitative data acquired from the survey applied before and after the Young Athletes Project which were then presented as tables. Descriptive analysis approach was used in the analysis of interview data. Because, descriptive analysis approach enables the organization of the data according to the subjects put forth by the study results and their presentation by taking into consideration the questions or dimensions used during the interview (Yıldırım \& Şimşek, 2013).The descriptive analysis process in the study was comprised of four stages which were; formation of the thematic framework, data processing in 
accordance with the thematic framework, defining the findings and interpretation of the findings. Direct quotations were made from participant opinions in order to indicate that the findings acquired as a result of data analysis reflect the opinions of the participants. Qualitative and quantitative data obtained in this study from families and volunteers were handled and presented within the framework of the study problem. In addition, the concepts of special athlete, partner athlete parent and partner volunteer were used for defining the families and volunteers who participated in the study.

\section{Results}

In this section, results for the opinions of special athlete and partner parents along with partner volunteers on the Young Athletes Project have been presented in line with the objective of the study.

Table 1. Opinions of special athlete parents on the Young Athletes Project before and after application

\begin{tabular}{|c|c|c|c|c|}
\hline & \multicolumn{2}{|c|}{$\begin{array}{c}\text { Before } \\
\text { the Program } \\
n=45\end{array}$} & \multicolumn{2}{|c|}{$\begin{array}{c}\text { After } \\
\text { the Program } \\
n=46\end{array}$} \\
\hline & Yes & No & Yes & No \\
\hline & $\%$ & $\%$ & $\%$ & $\%$ \\
\hline Does your child have a friend without any disability? & 64.4 & 35.6 & 93.5 & 6.5 \\
\hline $\begin{array}{l}\text { Does your child participate in social environments where he/she comes together with } \\
\text { other children (without any disability)? }\end{array}$ & 75.6 & 24.4 & 95.7 & 4.3 \\
\hline Did your child ever establish friendship with other children? & 64.4 & 35.6 & 87 & 13 \\
\hline Did your child ever perform sports activities with other children? & 35.6 & 64.4 & 84.8 & 15.2 \\
\hline Did your child ever go somewhere with other children? & 55.6 & 44.4 & 63 & 37 \\
\hline $\begin{array}{l}\text { Did your child ever attend cultural activities with other children such as theater, } \\
\text { cinema etc.? }\end{array}$ & 28.9 & 71.1 & 45.7 & 54.3 \\
\hline Did your child ever act in a theater play with other children? & 13.3 & 86.7 & 17.4 & 82.6 \\
\hline Did your child ever play a musical instrument? & 24.4 & 75.6 & 30.4 & 69.6 \\
\hline Did your child ever sing songs with other children? & 44.4 & 55.6 & 60.9 & 39.1 \\
\hline Did your child ever play games with other children? & 73.3 & 26.7 & 93.5 & 6.5 \\
\hline
\end{tabular}

Table 2. Opinions of special athlete parents on the communication of their children with their peers before and after the Young Athletes Project

\begin{tabular}{|c|c|c|c|c|c|c|c|c|c|}
\hline \multicolumn{2}{|c|}{ Very Good } & \multicolumn{2}{|c|}{ Good } & \multicolumn{2}{|c|}{ Moderate } & \multicolumn{2}{|c|}{ Not Good } & \multicolumn{2}{|c|}{ Very Bad } \\
\hline Before the & After & Before the & After & Before & After & Before the & After & Before the & After \\
\hline Program & the & Program & the & the & the & Program & the & Program & the \\
\hline$\%$ & Program & $\%$ & Program & Program & Progra & $\%$ & Program & $\%$ & Program \\
\hline \multirow[t]{3}{*}{$\mathrm{n}=45$} & $\%$ & $\mathrm{n}=45$ & $\%$ & $\%$ & $\mathrm{~m}$ & $\mathrm{n}=45$ & $\%$ & $\mathrm{n}=45$ & $\%$ \\
\hline & $\mathrm{n}=46$ & & $\mathrm{n}=46$ & $\mathrm{n}=46$ & $\%$ & & $\mathrm{n}=46$ & & $\mathrm{n}=46$ \\
\hline & & & & & $\mathrm{n}=46$ & & & & \\
\hline 8.9 & 17.4 & 22.2 & 26.1 & 35.6 & 39.1 & 31.1 & 17.4 & 2.2 & 0 \\
\hline
\end{tabular}

Special athletes having a friend with no disabilities increased by $29 \%$ following the 8 week game focused study for developing the basic motor skills by bringing together children with and without special education requirements. The number of social environments where special athletes come together with children having no disabilities increased by $20 \%$. Special athletes befriending other children increased by $22,6 \%$, whereas performing sportive activities with other children increased by $49,2 \%$. The percentage of special athletes going out with other children increased by $7.4 \%$, while the percentage of participating in cultural activities increased by $16,8 \%$. The percentage of special athletes acting in a theater play with other children increased by $4,1 \%$, whereas the ratio of playing a musical instrument increased by $6 \%$. An increase of $16,5 \%$ was observed in the percentage of special athletes singing songs with other children, while the ratio of special athletes playing games with other children increased by $20,2 \%$. The parents are of the opinion that the communication of special athletes with their peers developed in comparison with the pre-test values (Table 1 and Table 2). 
Table 3. Opinions of partner athlete parents on the Young Athletes Project before and after the application

\begin{tabular}{|c|c|c|c|c|}
\hline & \multicolumn{2}{|c|}{$\begin{array}{c}\text { Before } \\
\text { the Program } \\
n=60\end{array}$} & \multicolumn{2}{|c|}{$\begin{array}{c}\text { After } \\
\text { the Program } \\
n=51\end{array}$} \\
\hline & Yes & No & Yes & No \\
\hline & $\%$ & $\%$ & $\%$ & $\%$ \\
\hline Do you know of any child with special education requirement (mentally disabled)? & 61.7 & 38.3 & 74.5 & 25.5 \\
\hline Did your child ever befriend an individual with special education requirement? & 35 & 65 & 70.6 & 29.4 \\
\hline $\begin{array}{l}\text { Did your child ever perform sportive activities with an individual with special education } \\
\text { requirement? }\end{array}$ & 26.7 & 73.3 & 68.6 & 31.4 \\
\hline Did your child ever go somewhere with other children with special education requirement? & 25 & 75 & 49 & 51 \\
\hline $\begin{array}{l}\text { Did your child ever attend cultural activities such as theater, cinema etc.with children with } \\
\text { special education requirement? }\end{array}$ & 11.7 & 88.3 & 11.8 & 88.2 \\
\hline Did your child ever act in a theater play with children with special education requirement? & 3.3 & 96.7 & 9.8 & 90.2 \\
\hline $\begin{array}{l}\text { Did your child ever play a musical instrument with individuals with special education } \\
\text { requirement? }\end{array}$ & 5 & 95 & 7.8 & 92.2 \\
\hline Did your child ever sing songs with other children with special education requirement? & 18.3 & 81.7 & 51 & 49 \\
\hline Did your child ever play games with other children with special education requirement? & 38.3 & 61.7 & 66.7 & 33.3 \\
\hline $\begin{array}{l}\text { Do you think your child may play games with children with special education } \\
\text { requirement? }\end{array}$ & 91.7 & 8.3 & 88.2 & 11.8 \\
\hline
\end{tabular}

Table 4. Opinions of partner athlete parents on the communication of their children with their peers before and after the Young Athletes Project

\begin{tabular}{|c|c|c|c|c|c|c|c|c|c|}
\hline \multicolumn{2}{|c|}{ Very Good } & \multicolumn{2}{|c|}{ Good } & \multicolumn{2}{|c|}{ Moderate } & \multicolumn{2}{|c|}{ Not Good } & \multicolumn{2}{|c|}{ Very Bad } \\
\hline Before the & After & Before the & After & Before & After & Before the & After & Before the & After \\
\hline Program & the & Program & the & the & the & Program & the & Program & the \\
\hline$\%$ & Program & $\%$ & Program & Program & Program & $\%$ & Program & $\%$ & Program \\
\hline $\mathrm{n}=60$ & $\%$ & $\mathrm{n}=60$ & $\%$ & $\%$ & $\%$ & $\mathrm{n}=60$ & $\%$ & $\mathrm{n}=60$ & $\%$ \\
\hline & $\mathrm{n}=51$ & & $\mathrm{n}=51$ & $\mathrm{n}=60$ & $\mathrm{n}=51$ & & $\mathrm{n}=51$ & & $\mathrm{n}=51$ \\
\hline 53.3 & 56.9 & 38.3 & 35.3 & 6.7 & 5.9 & 1.7 & 0 & 0 & 2 \\
\hline
\end{tabular}

Percentage of partner athlete parents knowing a mentally disabled child increased by $12,8 \%$ after the program in comparison with the pre-test. Whereas the friendship status of mentally disabled individuals and partner athletes increased by $35,6 \%$ in comparison with the pre-test. Percentage of partner athletes performing sportive activities with mentally disabled individuals increased by $41.9 \%$ in comparison with the pre-test. The percentage of mentally disabled individuals going out with partner athletes increased by $24 \%$ in comparison with the pre-test. An increase of $32.7 \%$ was observed in partner athletes singing songs with mentally disabled individuals. Percentage of partner athletes playing games with mentally disabled individuals increased by $28.4 \%$ in comparison with the pre-test. It was observed upon examining the net score that the communication of partner athletes with their peers was almost the same (Table 4 and Table 5). 
Table 5. Opinions of volunteer partners on the Young Athletes Project before and after the application

\begin{tabular}{|c|c|c|c|c|}
\hline & \multicolumn{2}{|c|}{$\begin{array}{c}\text { Before } \\
\text { the Program } \\
n=119\end{array}$} & \multicolumn{2}{|c|}{$\begin{array}{c}\text { After } \\
\text { the Program } \\
n=107\end{array}$} \\
\hline & Yes & No & Yes & No \\
\hline & $\%$ & $\%$ & $\%$ & $\%$ \\
\hline $\begin{array}{l}\text { Can individuals with special education requirement establish friendship with individuals } \\
\text { who have no disability? }\end{array}$ & 96.6 & 3.4 & 96.3 & 3.7 \\
\hline $\begin{array}{l}\text { Can individuals with special education requirement perform sportive activities with } \\
\text { individuals who have no disability? }\end{array}$ & 89.1 & 10.09 & 97.2 & 2.8 \\
\hline $\begin{array}{l}\text { Can individuals with special education requirement go out with individuals who have no } \\
\text { disability? }\end{array}$ & 97.5 & 2.5 & 95.3 & 4.7 \\
\hline $\begin{array}{l}\text { Can individuals with special education requirement attend cultural activities such as } \\
\text { theater, cinema etc. with individuals who have no disability? }\end{array}$ & 93.3 & 6.7 & 90.7 & 9.3 \\
\hline $\begin{array}{l}\text { Can individuals with special education requirement ever act in a theater play with } \\
\text { individuals who have no disability? }\end{array}$ & 83.2 & 16.8 & 82.2 & 17.8 \\
\hline $\begin{array}{l}\text { Can individuals with special education requirement ever play a musical instrument with } \\
\text { individuals who have no disability? }\end{array}$ & 89.1 & 10.9 & 86.9 & 13.1 \\
\hline $\begin{array}{l}\text { Can individuals with special education requirement sing songs with individuals who have } \\
\text { no disability? }\end{array}$ & 95.8 & 4.2 & 92.5 & 7.5 \\
\hline $\begin{array}{l}\text { Can individuals with special education requirement play games with individuals who have } \\
\text { no disability? }\end{array}$ & 97.5 & 2.5 & 98.1 & 1.9 \\
\hline
\end{tabular}

Table 6. Opinions of volunteer partners on the communication of their children with their peers before and after the Young Athletes Project

\begin{tabular}{|c|c|c|c|c|c|c|c|c|c|}
\hline \multicolumn{2}{|c|}{ Very Good } & \multicolumn{2}{|c|}{ Good } & \multicolumn{2}{|c|}{ Moderate } & \multicolumn{2}{|c|}{ Not Good } & \multicolumn{2}{|c|}{ Very Bad } \\
\hline $\begin{array}{c}\text { Before the } \\
\text { Program } \\
\% \\
n=119\end{array}$ & $\begin{array}{c}\text { After } \\
\text { the } \\
\text { Program } \\
\% \\
n=107\end{array}$ & $\begin{array}{c}\text { Before the } \\
\text { Program } \\
\% \\
n=119\end{array}$ & $\begin{array}{c}\text { After } \\
\text { the } \\
\text { Program } \\
\% \\
n=107\end{array}$ & $\begin{array}{c}\text { Before } \\
\text { the } \\
\text { Program } \\
\% \\
n=119\end{array}$ & $\begin{array}{c}\text { After } \\
\text { the } \\
\text { Program } \\
\% \\
\mathrm{n}=107\end{array}$ & $\begin{array}{c}\text { Before the } \\
\text { Program } \\
\% \\
\mathrm{n}=119\end{array}$ & $\begin{array}{c}\text { After } \\
\text { the } \\
\text { Program } \\
\% \\
\mathrm{n}=107\end{array}$ & $\begin{array}{c}\text { Before the } \\
\text { Program } \\
\% \\
n=119\end{array}$ & $\begin{array}{c}\text { After } \\
\text { the } \\
\text { Program } \\
\% \\
n=107\end{array}$ \\
\hline 7.6 & 12.1 & 29.4 & 36.4 & 47.1 & 35.5 & 15.1 & 12.1 & 1.8 & 2.8 \\
\hline
\end{tabular}

An increase of $6.2 \%$ occurred after the program in the percentage of previously working with mentally disabled individuals. The opinion that mentally disabled individuals may participate in sportive activities with individuals who have no disabilities increased by $8.1 \%$. Whereas opinions related with the other factors had similar values before and after the program.

\subsection{Interview Results}

In this section, in-depth interviews carried out with special athlete and partner athlete parents, project officers and project volunteers have been analyzed. When processes for taking part in the project were examined, different means of participation were observed for each partner: project officers are key individuals for putting the project in practice and completing it at the pre-determined institution and these individuals should be selected by the Special Olympics according to their areas of academic activity. Previous and current academic and field studies on «special athletes/special children» have been the determinant factors. Whereas project volunteers were faculty of education students selected with a motivation of voluntariness for directly assisting the project officers. The teachers who took part in the project were already taking part actively in teaching special children.

Project officers and teachers were the main sources of information for special athlete and partner athlete parents on the project objectives and procedures. It is indicated that teachers held an additional orientation meeting with the parents of special children in the integration class. Participation by the parents to this project which was essentially focused on «integration» turned out to be higher than expected. While the main motivation for the parents of special children was a very small communication skill that their children may develop as individuals with insufficient prior contact with the society, the motivation for partner athlete parents was to gain the ability to realize that their own children are «actually not different than» special children. The fact that theoretical courses on physical education, special education and rehabilitation etc. were put into practice on a voluntary basis during a 
devoted organization has moved up the Young Athletes Project to another level.

\subsubsection{Effects of the Project on the Volunteers}

It was determined following the interviews carried out with the volunteers that the project provided "a sense of usefulness" along with spiritual satisfaction. "Succeeding and struggling" has reinforced the sense of personal satisfaction for this young target group that previously did not find the means to contribute to their society. Volunteers also listed patience, anger management, taking initiative and crisis resolution as individual gains acquired from the project.

Volunteer partners indicated the following regarding their opinions on this issue:

I used to struggle with anger management and patience. One should be free of all kinds of anger, in particular, if you are dealing with a special child. This is what I learned(Partner volunteer 2).

I participated in the project to help them, but actually they ended up helping me. This has made me a whole new person. I am now a more controlled and understanding individual (Partner Volunteer 3).

\subsubsection{Effects of the Project on Special Athletes}

Information was acquired from all families for examining the effects of the project on special athletes. Young Athletes Project stands out for special athletes as a means of improving their social and communication skills. The most drastic change that the project has caused on special athletes is that they ended up becoming more open to communication by way of basic physical contact such as hugging, embracing and holding hands. This change is observed more clearly by the athlete parents and volunteers and especially covers up a much longed for gap in the relationship established with the parents.

Parents of special athletes indicated the following regarding their opinions on this issue:

He was a child who did not look at my face, could not make eye contact, never hugged and never talked with me. Now, he comes up to me every night and kisses me on the cheek. We have gained something very important. (Father of a child with autism)

The ability of my daughter to express herself is very weak; however, she tries to contact me after school by drawing pictures. She can now communicate with me. (Mother of a child with autism)

Another significant gain resulting from the project for special athletes who are disciplined harder and whose abilities to act in accordance with common rules has not developed much was the ability for «perceiving commands and adapting to them». Thanks to the playground and the activities plan for improving psychomotor skills, special athletes were able to adapt to basic common movement rules such as waiting in line, forming a circle, counting steps, following a friend at one side or in front.

One of the families expressed their opinions on this discipline, following the rules and the ability for common movement as follows:

At first, they would never wait in line or stand side by side with another person. They would not listen to us. They were discordant. Now, he holds his friend's hand and can stay in the game for 40 minutes (Mother of a mentally disabled child)

A volunteer partner indicated the impact of the program on special athletes as follows:

The most drastic change in special athletes was that they started to express themselves. They were more withdrawn, insecure. Overtime, they became open to communication. We feel that they started taking part in society (Partner volunteer 1).

The most important benefit provided by the project for partner athletes with normal development was learning that their peers with different behaviors than their own were actually «normal». In this regard, they gained the skill of empathy. When considered from the perspective of parents, their partner athlete children may state that special athletes are "like themselves" and that the child does not find it odd to see a person with disabilities in the society thus acting in a more natural manner in comparison with adults.

\subsubsection{Effects of the Project on Special Athletes}

The effects of the project were observed more clearly during interviews carried out with special athlete parents in comparison with partner athlete parents. Whereas this project is of great importance for partner athlete parents with children considered as "normal" by the society to raise sensitive children with high sensitivity towards their environment; this project is very important for special athlete parents because their children start to interact with their parents and their environment, improve their self-confidence, feel that they are loved and not excluded. 
Families express their opinions in this matter as follows:

I am willing to go along with my daughter calling me mother, sleeping with me and finishing the day without crying and having a nervous breakdown. This project succeeded to some extent (Special athlete parent 2).

Peer education was very important. Until now, there was no integration environment. He could not be efficient with children like him. Similarly, he was lost among normal children. (Special athlete parent 5).

I would not be able to do a better job if I talked to him face to face and taught him this is your friend. My child was able to learn it here (Partner athlete parent 3 ).

The project taught us the most humane emotion of all at a very early age through practice; compassion, protection and not seeing someone as different (Partner athlete parent 2).

For parents who are of the opinion that public awareness is low and that state planning is insufficient for a special child to reach a sustainable and healthy education, their children taking part in such a project is evaluated as a significant step. In this regard, majority of the parents who participated in the project asked for the project to continue for longer periods of time.

\section{Discussion}

The objective of this study was to examine the impact of special Olympics activities on the parents of children with special needs and normal developing children as well as volunteers who have a possibility to work with children with special needs and it was determined as a result of the study that both the parents and the partners were affected positively from the activities.

Mentally disabled children and normal developing children were put together from an early age as part of the Young Athletes Project thus somewhat being subject to integration. It can be stated according to the survey and interview results that both mentally disabled children and normal developing children are affected positively from the project. This may occur due to different reasons. One of these reasons may be the fact that the study was a sports-focused project. Many studies have been carried out on the impacts of sports on the general development of children with mental disabilities which have put forth the positive effects of sports on mentally disabled children. Gençöz (1997) carried out a study on the effects of basketball education on the behavior development of mentally disabled children as a result of which it was presented that there were positive changes in the behaviors of these children both in the family and in their classes. Chiang (2003) also carried out a study indicating that natural social interaction of autistic children increases as a result of physical activities in an entertaining environment while sense of loneliness decreases and friendship with peers is strengthened further. The importance of recreational activities for disabled individuals with regard to integration with their environment and the society, forming friendships and social acceptance was set forth in the study by McMahon (1998). Another reason for the positive impact may be due to the impact of integration on social skills. Integration is not an application that can be considered only within an academic context. It has positive impacts on social skills (Odom, Deklyen, \& Jenkings, 1984). The finding in the study by Özbaba (2000) that is in parallel with this result is that students with special needs learn the reinforced positive behaviors from their normal developing peers. Vaughn, Elbaum and Boardman (2001) carried out a study as a result of which it was put forth that whereas expectations for academic skills from integration students were low, expectations for social skills were higher. Moreover, it is also stated in various studies that integrated education approach encouraging social-emotional skills as an inseparable part of daily education enables children to develop their social-emotional skills (Burstein, Sears, Wilcoxen, Cabello, \& Spagna, 2004; Wigelsworth, Humphrey, \& Lendrum, 2012).

Mental disability is a continuous situation. A chronic disorder is a source of stress that the parents should continuously cope with (Friedrich, Wilturner, \& Cohen, 1985). Having a child with special needs is a very difficult situation that places limitations on the lives of the parents and requires efforts for adaptation. Special variables such as economic difficulties, lack of knowledge, tension inside the family, decrease in participation to social activities, attitude of the society towards mentally disabled individuals have been indicated as fundamental difficulties for families of children with special needs (Dyson, 1999). Mothers generally play a more active role in solving these difficulties and they strive harder (Dönmez, Bayhan, \& Artan, 2000; Özsenol et al., 2003). Families are mostly insufficient in coping with this high stress, long term problem and undergo various behavioral and emotional problems. One of these problems is that children with special needs cannot establish contact with other individuals and this has a negative impact on his/her social relations (Kargın, Acarlar, \& Sucuoğlu, 2003). It can be indicated that the opinions of the parents of children with special needs on their child participating in activities together with other children changed in a positive direction in this study following the Young Athletes Project. In the project, special child parents observed that their children with special needs participated without any problem 
in sports activities together with other children. This experience had an impact on their negative opinions. It is possible that the short term change was due to the impact of early education. It becomes more difficult at later ages for individuals with special education requirement to increase their social interaction with other individuals (Sucuoğlu \& Kargın, 2012). Contrary to this, there are many studies indicating that early education studies increase the development of children with special needs (Salend, 2001). Therefore, it can be stated that early education has a positive impact not only on children with special needs, but also on their families.

The objective of Young Athletes Project was to eliminate prejudices at an early age and improving their skills to take part in society. Positive feedbacks from families and volunteers as well as children were taken in the study group regarding this objective. It was determined as a result of family interviews that there is a demand for such studies to be carried out over a longer period of time. Willingness of families for such studies leads us to think that the positive impact of integration will increase in the future. Because, it is important for a variety of reasons to understand the opinions on integration of the families of disabled children. The first reason is that families of disabled children play a deciding role in the evaluation, placement, formation of the education programs of their children and the inspection of the provided services (Fisher, Pumpian, \& Sax, 1998). Secondly, families play an informative and supportive role in the education of their children (Duhaney \& Salend, 2000). Thirdly, families are driving forces for the attainment of services that their children will require and the fulfilling of the legal requirements while also leading the planning activities for prospective services (Duhaney \& Salend, 2000; Palmer, Fuller, Arora, \& Nelson, 2001). When considered from these perspectives, it is possible to indicate that the project may have positive impacts on the future for the families of children with special needs. It has also been set forth in various other studies that family participation and advanced peer relations may have a positive impact on the school environment and the related perceptions of students (McLeskey \& Waldron, 2007).

Another impact of the Young Athletes Project was on the families of children with normal development. The fact that majority of the children did not have any prior experience with disabled children may have had a positive impact, however carrying out sports activities with them for a period of 8 weeks may have also increased this effect. Literature survey reveals that the attitudes of families of children with normal development change positively over time when their children receive an integration education including children with special needs. Gottlieb and Leyser (1996) carried out two evaluations separated by a decade regarding the attitudes of the parents of children with normal development in normal classrooms together with children with special needs. Both evaluations compared the attitudes of parents who have an individual with special needs in their family with the attitudes of parents who do not have any individual with special needs in their family. An important finding of the study was that families with an individual with special needs displayed positive attitudes in the second evaluation. Baykoç-Dönmez, Aslan, and Avcı (1997) carried out a study in which it was determined that students with normal development and their parents are willing to help individuals with special needs. In yet another study by Öncül and Batu (2005), it was indicated that the mothers of children with normal development had positive attitudes towards integration application, however it was also shown that they do not have sufficient knowledge on the integration application. Özbaba (2000) determined the attitudes of pre-school educators and families on the integration of children with normal development and children with special needs. It was determined that the attitudes on integration during the pre-school period of parents of children with normal development were affected positively when they have a child with special needs. None of the partner athlete parents in this study had an individual with special needs in their families. In this regard, it was observed upon an evaluation of the study results that partner athlete parents developed a positive attitude towards integration at an early age even though they did not have any individual with special needs in their families.

It can be stated that there were positive changes in the opinions of the volunteer partners who participated in the project for helping mentally disabled children and normal developing children to carry out sportive activities together. This change was not as drastic as those of the parents. The reason for this may be due to the fact that volunteer partners had similar experiences prior to the project and their feelings of devotion to this project. However, an important point here is that volunteers have started working with mentally disabled children during their education. When the volunteers are considered as teacher candidates of the future, it is thought that the experience they underwent will have a significant impact on their professional lives. Because ultimately, the education of individuals with special needs shall depend on the approach of their teachers (Salend \& Garrick-Duhaney, 1999). Success of integration applications depends on individuals with special needs receiving special education and normal education services at sufficient levels. Providing these services in a sufficient manner depends on fulfilling various conditions (Causton-Theoharis, Theoharis, Bull, Cosier, \& Dempf-Aldrich, 2011). Normal developing children, children with special needs, parents, school staff and general education classes should be prepared for integration education and they should be able to work in cooperation in order for integration 
applications to be successful (Kargin, 2006). At this point, the most important factor in integration applications is the teacher. It is important that the teacher prepares for a student perhaps with certain characteristics about whom the teacher has no previous knowledge of. Another factor that is as important as preparing the teacher is the necessity for teachers who will take part in integration classrooms to be willing for integration and display accepting attitudes towards the disabled student (Kargin, 2006; Salend \& Garrick-Duhaney, 1999). In this regard, it is thought that early special education experience of the volunteer partners who participated in the Young Athletes Project may increase the chances of developing positive attitudes regarding the education of children with special needs. Booth and Ainscow (2002) claim that the advancement related with the formation of positive school environments may be accomplished in a relatively shorter period of time with certain priorities. This study has pointed out that the classroom participation of disabled individuals may be increased along with their communication with their peers and the school staff as a result of integration education. This is associated with the fact that the attitudes of the school staff and families are shaped around the principles of equality, variety and the belief that all students can learn together (Dyson, Howes, \& Roberts, 2002). It can be put forth that this belief has been formed over volunteer partners.

Even though the Young Athletes Project was an 8 week short project, it is believed to have positive impacts on both the present and future of children with special needs. Based on the study results, it can be suggested to carry out similar studies especially during the early childhood period in order to eliminate prejudices and to improve relations. In addition, the impacts of similar studies on children, families and educators may be examined by way of experimental studies.

\section{Acknowledgments}

This study was conducted with the support of "Special Olympics Turkey". I would like to express my appreciation to Didem Ünsür, the country director of Special Olympics Turkey.

\section{References}

Aysan, F., \& Özben, Ş. (2010). Engelli çocuğu olan anne babaların yaşam kalitelerine ilişkin değişkenlerin incelenmesi. Buca Ĕ̈itim Fakültesi Dergisi, 22, 1-6.

Bahar, A., Bahar, G., Savaş, H. A., \& Parlar, S. (2009). Engelli çocukların annelerinin depresyon ve anksiyete düzeyleri ile stresle başa çıkma tarzlarının belirlenmesi. Fırat Sağlık Hizmetleri Dergisi, 4(11), 97-112.

Baykoç-Dönmez, N., Avc1, N., \& Aslan, N. (1997). Normal gelişim gösteren ögrenci ve velilerinin engellilere ve entegrasyona bakışları 1. Ulusal Çocuk Gelişimi ve Eğitimi Kongresi’nde sunulmuş bildiri, Ankara.

Bondurant, B. J. (2004). Tecahers attitudes towards inclusion (Unpublished master thesis). California State University.

Booth, T., \& Ainscow, M. (2002). Index for inclusion: Developing learning and participation in schools. Centre for Studies on Inclusive Education (CSIE), Rm 2S203 S Block, Frenchay Campus, Coldharbour Lane, Bristol BS16 1QU, United Kingdom, England.

Borg, W. R., Gall, J. P., \& Gall, M. D. (1993). Applying educational research (3th ed.). New York: Longman.

Burstein, N., Sears, S., Wilcoxen, A., Cabello, B., \& Spagna, M. (2004). Moving toward inclusive practices. Remedial and Special Education, 25(2), 104-116. https://doi.org/10.1177/07419325040250020501

Campbell, J., Gilmore, L., \& Cuskelly, M.(2003). Changing student teachers' attitudes towards disability and inclusion. Journal of Intellectual \& Developmental Disability, 28(4), $369-379$. https://doi.org/10.1080/13668250310001616407

Causton-Theoharis, J., Theoharis, G., Bull, T., Cosier, M., \& Dempf-Aldrich, K. (2011). Schools of Promise: A School District-University Partnership Centered on Inclusive School Reform. Remedial and Special Education, 32(3), 192-205. https://doi.org/10.1177/0741932510366163.

Cavkaytar, A. (2000). Zihin engellilerin eğitim amaçları. Anadolu Üniversitesi Eğitim Fakültesi Dergisi, 10(1), $115-121$.

Chiang, I. T. (2003). Effects of a therapeutic recreation intervention within a technology-based physical activity context on the social interaction of male youth with autism spectrum disorders (Doctoral dissertation, Kinesiology Publications, University of Oregon).

Cohen, L., \& Manion, L. (1997). Reseacrh methods in education (4th ed.). Routledge: London and New York.

Çürük, N. (2008). Ankara İl Merkezi'nde Bulunan Milli Eğitim Bakanlığı'na bağlı İş Okullarında 1. ve 4. sınıfa devam eden zihinsel engelli çocukların annelerinin kaygı ve sosyal destek düzeylerinin karsılastıkları 
problemlere göre incelenmesi. Journal of Intellectual Disability Research, 12, 862-873.

Dereli, F., \& Okur, S. (2008). Engelli çocuğa sahip ailelerin depresyon durumunun belirlenmesi, Yeni Tip Dergisi, $25,164-158$.

Diken, İ. H., \& Sucuoğlu, B. (1999). Sınıfında zihin engelli çocuk bulunan ve bulunmayan sınıf öğretmenlerinin zihin engelli çocukların kaynaştırılmasına yönelik tutumlarının karşılaştırılması. Ankara Üniversitesi Ĕgitim Bilimleri Fakültesi Özel Eğitim Dergisi, 2(3), 25-39. https://doi.org/10.1501/Ozlegt_0000000042

Dönmez, N., Bayhan, P., \& Artan, İ. (2000). Engelli çocuğa sahip ailelerin beklentileri ve endişe duydukları konuların incelenmesi. Sosyal Hizmetler Dergisi, 1(11), 16-23.

Duhaney, L. M., \& Salend, S. J. (2000). Parental perceptions of inclusive educational placements. Remedial and Special Education, 21(2), 121-128. https://doi.org/10.1177/074193250002100209

Dyson, A., Howes, A., \& Roberts, B. (2002). A systematic review of the effectiveness of school-level actions for promoting participation by all students. EPPI-Centre, Social Science Research Unit, Institute of Education, University of London.

Dyson, L. L. (1991). Families of young children with handicaps: Parental stress and family functioning. American Journal on Mental Retardation.

Ekiz, D. (2003). Eğitimde araştırma yöntem ve metotlarına giriş. Ankara.

Fakolade, O. A., Adenıyı, S. O., \& Tella, A. (2009). Attitude of teachers towards the inclusion of special needs children in general education classroom: the case of teachers in some selected schools in Nigeria. International Electronic Journal of Elementary Education, 1(3), 155-169.

Fırat, T. (2014). Farklı eğitim kademelerinde görev yapacak öğretmen adaylarının kaynaştırmaya yönelik tutumlarının incelenmesi. Adryaman Üniversitesi Sosyal Bilimler Enstitüsü Dergisi, 2014(18). https://doi.org/10.14520/adyusbd.808

Fisher, D., Pumpian, I., \& Sax, C. (1998). High school students attitudes about and recommendations for their peers with significant disabilities. Journal of the Association for Persons with Severe Handicaps, 23(3), 272-282. https://doi.org/10.2511/rpsd.23.3.272

Fraenkel, J. R., \& Wallen, N. E. (1996). How to design and evaluate research (3th ed.). New York: McGraww-Hill.

Friedrich, W. N., Wilturner, L. T., \& Cohen, D. S. (1985). Coping resources and parenting mentally retarded children. American Journal of Mental Deficiency.

Garrick-Duhaney, L. M., \& Salend, S. J. (2000). Parental perceptions of inclusive educational placements. Remedial and Special Education, 21(2), 121-128. https://doi.org/10.1177/074193250002100209

Gençöz, F. (1997). The effects of basketball training on the maladaptive behaviors of trainable mentally retarded children. Research in Developmental Disabilities, $18(1), \quad 1-10$. https://doi.org/10.1016/S0891-4222(96)00029-7

Gottlieb, J., \& Leyser, Y. (1996). Attitudes of public school parents toward mainstreaming: Changes over a decade. Journal of Instructional Psychology, 23(4), 257.

Gözün, Ö., \& Yıkmış, A. (2004). Öğretmen Adaylarının Kaynaştırma Konusunda Bilgilendirilmelerinin Kaynaştırmaya Yönelik Tutumlarının Değişimindeki Etkililiği. Ankara Üniversitesi Eğitim Bilimleri Fakültesi Özel Eğitim Dergisi, 5(2), 65-77. https://doi.org/10.1501/Ozlegt_0000000081

Güzel-Özmen, R. (2003). Kaynaştırma ortamlarında öğretimsel düzenlemeler. A. Ataman (Editör). Özel Gereksinimli Çocuklar ve Özel Eğitime Giriş.

Hallahan, D. P., \& Kaufman, H. (2006). Exceptional Learners: Introduction to special education. Boston:Pearson Education.

Heward, W. L. (2013). Excetional learners introduction to special education. Boston: Pearson Education.

IDEA. (2012). Retrieved from http://idea.ed.gov/

Kaner, S. (2000). Özel eğitime giriş dersinin, öğretmen adaylarının zihinsel engellilere yönelik tutumlarına etkisi. Çocuk Gelişimi ve Ĕ̈itimi Dergisi, 1(1), 32-43.

Karaçengel, F. (2007). Zihinsel engelli çocuğa sahip anneler ile sağllklı çocuğa sahip annelerin atılganlık ve suçluluk-utanç düzeyleri açısından karşılaştırllması. Yayınlanmamış Yüksek Lisans Tezi, Maltepe 
Üniversitesi, Sosyal Bilimler Enstitüsü, İstanbul.

Karasar, N. (2003). Bilimsel Araştırma Yöntemi (12. Baskı). Ankara: Nobel Yayın Dağıtım.

Kargın, T. (2004). Kaynaştırma: tanımı, gelişimi ve ilkeleri. Ankara Üniversitesi Eğitim Bilimleri Fakültesi Özel Eğitim Dergisi, 5(2), 1-13. https://doi.org/10.1501/Ozlegt_0000000080

Kargın, T. (2006). Kaynaştırma: Temel Kavramlar, Tarihçe Ve İlkeler (İçinde). In A. Oktay, \& Ö. Polat-Unutkan (Eds), İlkögretimde kaynaştırma uygulamaları: Yaklaşımlar, yöntemler, teknikler. İstanbul: Morpa Kültür Yayınları.

Kargın, T., Acarlar, F., \& Sucuoğlu, B. (2003). Öğretmen, yönetici ve anne-babaların kaynaştırma uygulamalarına ilişkin görüşlerinin belirlenmesi. Ankara Üniversitesi Eğitim Bilimleri Fakültesi Özel Ĕgitim Dergisi, 4(2), 55-76. https://doi.org/10.1501/Ozlegt_0000000207

Kırcaali-İftar, G. (1998). Özel gereksinimli bireyler ve özel eğitim. Eripek (Ed.), Özel Eğitim (pp. 1-14). Eskişehir: Anadolu Üniversitesi Yayınları.

Mcleskey, J., \& Waldron, N. L. (2007). Making differences ordinary in inclusive classrooms. Intervention in School and Clinic, 42(3), 162-168. https://doi.org/10.1177/10534512070420030501

McMahon, D. J. (1998). Social acceptance of children with developmental handicaps in integrated daycamps (Doctoral dissertation, National Library of Canada $=$ Bibliothèque nationale du Canada).

MEB, (2012). Özel eğitim hizmetleri yönetmeliği. Retrieved from https://orgm.meb.gov.tr/meb_iys_dosyalar/2012_10/10111226_ozel_egitim_hizmetleri_yonetmeligi_son.pd $\mathrm{f}$

Miles, M. B., \& Huberman, A. M. (1994). Qualitative data analysis (2nd ed.). California: Sage Publication.

Moostropieri, A. M., \& SCRUGGS, E. T. (2000). The Inclusive classroom. Strategies for effective instruction. New Jersey: Prentice Hall.

Natan, K. (2007). Zihinsel engelli çocuğu olan ve olmayan annelerin depresyon ve kaygl düzeyleri. Yayınlanmamış Yüksek Lisans Tezi, Maltepe Üniversitesi, İstanbul.

Odom, S. L., Deklyen, M., \& Jenkins, J. R. (1984). Integrating handicapped and nonhandicapped preschoolers: Developmental impact on nonhandicapped children. Exceptional Children, 51(1), 41-48.

Odom, S. L., Horner, R. H., \& Snell, M. E. (Eds.). (2007). Handbook of developmental disabilities. New York: Guilford press. https://doi.org/10.1177/001440298405100106

Olson, J. M. (2003). Special education and general education teacher attitudes toward inclusion (Unpublished master thesis). University of Wisconsin-Stout.

Öncül, N., \& Batu, E. S. (2005). Normal gelişim gösteren çocuk annelerinin kaynaştırma uygulamasına ilişkin görüşleri. Ankara Üniversitesi Ĕgitim Bilimleri Fakültesi Özel Ĕgitim Dergisi, 6(2), 37-54. https://doi.org/10.1501/Ozlegt_0000000090

Orel, A., Zerey, Z., \& Toret, G. (2004). Sınıf öğretmeni adaylarının kaynastırmaya yönelik tutumlarinin incelenmesi [An analysis of the classroom teachers $\Gamma$ attitudes towards inclusion]. Ankara Universitesi Egitim Bilimleri Fakultesi Ozel Egitim Dergisi, 5, 23-33.

Özbaba, N. (2000). Okul öncesi eğitimcilerin ve ailelerin özel eğitime muhtaç çocuklar ile normal çocukların entegrasyonuna (kaynaştırılmasına) karşı tutumları. Marmara Üniversitesi, Eğitim Bilimleri Enstitüsü, İstanbul.

Özşenol, F., Iş̧ıhan, V., Ünay, B., Aydın, H. İ., Akın, R., Gökçay, E. (2003). Engelli çocuğa sahip ailelerin aile işlevlerinin değerlendirilmesi. Gülhane Tip Dergisi, 45(2), 156-164.

Palmer, D., Fuller, K., Arora, T., \& Nelson, M. (2001). Taking sides: Parent views on inclusion for their children with severe disabilities. Exceptional Children, 67(4), 467-484. https://doi.org/10.1177/001440290106700403

Patton, M. Q. (1990). Qualitative Evaluation and Research Methods (2nd ed.). Newbury Park, CA. Sage.

Rakap, S., \& Kaczmarek, L. (2010). Teachers' attitudes towards inclusion in Turkey. European Journal of Special Needs Education, 25(1), 59-75. https://doi.org/10.1080/08856250903450848

Salend, J. S. (2001). Creating inclusive classrooms. Effective and leftective prractices (4th ed.). New Jersey, Prentice Hall. 
Salend, S. J., \& Garrick-Duhaney, L. M. (1999). The impact of inclusion on students with and without disabilities and their educators. Remedial and special education, 20(2), 114-126. https://doi.org/10.1177/074193259902000209

Smith, T. E. C., Polloway, E. A. Patton, R., \& Dowdy, C. A. (2008). Teaching students with special needs in inclusive settings.

Sucuoğlu, B., \& Bakkaloğlu, H. (2013). Okul öncesinde kaynaştırma. Ankara: Kök Yayıncılık.

Sucuoğlu, B., \& Kargın, T. (2012) İlköğretimde Kaynaştırma Uygulamaları. Ankara: Kök Yayıncılık.

Turnbull, R., Turnbull, A., Shank, M. S. S., \& Leal, D. (2002). Exceptional Lives: Special Education in Today's Schools. Merrill Prentice Hall.

Uğuz, Ş., Toros, F., İnanç, B. Y., \& Çolakkadıŏglu, O. (2004). Zihinsel ve/veya bedensel engelli çocukların annelerinin anksiyete, depresyon ve stres düzeylerinin belirlenmesi. Klinik Psikiyatri, 7(1), 42-47.

Vaughn, S., Elbaum, B., \& Boardman, A. G. (2001). The social functioning of students with learning disabilities: Implications for inclusion. Exceptionality, 9(1-2), 47-65. https://doi.org/10.1080/09362835.2001.9666991

Villa, R. A., \& Thousand, J. S. (2003). Making inclusive education work. Educational Leadership, 61(2), 19-19.

Webber, J., \& Scheuermann, B. (2008). Educating students with autism: A quick start manual. Pro-Ed, Inc.

Wigelsworth, M., Humphrey, N., \& Lendrum, A. (2012). A national evaluation of the impact of the secondary social and emotional aspects of learning (SEAL) programme. Educational Psychology, 32(2), 213-238. https://doi.org/10.1080/01443410.2011.640308

Yıldırım, A., \& Şimşek, H. (2013). Sosyal bilimlerde nitel araştırma yöntemleri (9. baskı). Ankara: Seçkin Yayıncilik.

\section{Copyrights}

Copyright for this article is retained by the author(s), with first publication rights granted to the journal.

This is an open-access article distributed under the terms and conditions of the Creative Commons Attribution license (http://creativecommons.org/licenses/by/4.0/). 